\title{
Spatio-temporal trends of PCBs in the Swedish freshwater environment 1981-2012
}

\author{
Elisabeth Nyberg, Sara Danielsson, Ulla Eriksson, Suzanne Faxneld, \\ Aroha Miller, Anders Bignert
}

\begin{abstract}
Polychlorinated biphenyls (PCBs) have been monitored in perch (Perca fluviatilis), pike (Esox lucius), and Arctic char (Salvelinus alpinus) in reference lakes since the late 1960s. Temporal trends and spatial patterns are currently monitored in nine and 32 lakes, respectively. Overall, PCB concentrations are decreasing. However, this is not consistent for all congeners across all lakes and species. Perch has comparatively low PCB concentrations relative to suggested target levels, but individual congener concentrations in some lakes are concerningly high. No temporal trend is seen for CB-118 and CB-153 in perch, but significant decreasing trends exist for Arctic char and pike, for which monitoring started earlier than for perch. The lower/higher chlorinated congener ratio decreased over time in most lakes, indicating fewer new emissions. CB-118 and CB-153 concentrations in perch show spatial gradients across Sweden, with higher concentrations found near urban/industrial areas.
\end{abstract}

Keywords Fish P PCBs - Monitoring - Freshwater · Sweden · Trends

\section{INTRODUCTION}

Polychlorinated biphenyls (PCBs) are one of the 12 groups of persistent organic pollutants (POPs) originally included in the Stockholm Convention on POPs. ${ }^{1}$ PCBs have been used in a wide variety of manufacturing processes, especially as plasticizers and insulators, and are widely distributed in the environment. In 1973, PCB use was banned

\footnotetext{
${ }^{1} \mathrm{http} / / / \mathrm{chm}$. pops.int/TheConvention/ThePOPs/ListingofPOPs/tabid/ 2509/Default.aspx.
}

in Sweden, except within sealed systems. In 1978, the ban was extended to prohibit all new use of PCBs.

PCBs can influence human health by affecting multiple organ systems (Carpenter 1998, 2006). Their toxicological effects on, for example, reproduction in mink are well documented (Aulerich and Ringer 1977; Bleavins et al. 1980). Animals in aquatic systems tend to biomagnify contaminants at a higher degree compared to terrestrial species due to the complexity and omnivory that characterizes aquatic food webs (Zanden and Rasmussen 1996). The concentrations of PCBs are generally positively correlated with the trophic position of a fish population within an aquatic food chain and are particularly high in predatory fish species (Brázová et al. 2012).

In the mid-1960s, research concerning environmental contaminant concentrations (e.g., chlorinated contaminants and heavy metals) and abundance, and their effects on wildlife began at the Swedish Museum of Natural History (SMNH) because of adverse health effects being observed in top predators such as Baltic grey seals (Halichoerus grypus) and white tailed sea eagles (Haliaeetus albicilla) (Helle et al. 1976a, b; Helander et al. 2002; Bredhult et al. 2008). During the 1970s, initial efforts were made to establish an environmental contaminant research program. In 1980, a comprehensive national monitoring program for environmental quality was formed by the Swedish Environmental Protection Agency (SEPA). SMNH was appointed the responsible institute for monitoring environmental contaminants in biological samples. The chemical analysis has been carried out at the same laboratory since the start of the monitoring program. The laboratory was initially a part of the SEPA and, since 1992, a part of Stockholm University (SU).

The primary objectives of the monitoring program were (1) to measure the concentrations of various contaminants and estimate normal variation in freshwater biota from 
representative sites throughout the country that were uninfluenced by local sources; (2) to describe the general contaminant load and to supply reference values that could be used for comparison with data from regional and local monitoring programs; (3) to monitor long-term time trends and estimate the rate of changes found; (4) to estimate the response in biota to actions taken to reduce the discharge of various contaminants; (5) to detect incidents of regional, national or international influence; (6) to detect renewed usage of banned contaminants for compliance monitoring, and (7) to discover large scale spatial differences across the country.

Sweden is a country with many lakes that cover more than $9 \%$ of the country's total surface area. The lakes within the Swedish National Monitoring Program for Contaminants in Freshwater Biota (SNMPCFB) are distributed from the northern parts of Sweden (Lake Abiskojaure) located $200 \mathrm{~km}$ north of the Arctic Circle, to the southern-most parts (Lake Krageholmssjön), with the majority located in the southern half of Sweden. The large distances between north and south leads to large temperature differences, thus some of the lakes are covered with ice for several months of the year, while others remain ice-free. The lakes also differ in size, nutrient status, general physical environment, and land use of surrounding areas. The smallest lake is $0.06 \mathrm{~km}^{2}$ (Lake Skärgölen) and the largest is $184 \mathrm{~km}^{2}$ (Lake Bolmen). These physical differences imply a great variability between the lakes concerning abiotic factors that might affect contaminant levels in fish.

Here we examine temporal and spatial relationships of $\mathrm{PCB}$ congeners (CB-28, CB-52, CB-101, CB-118, CB-138, CB-153 and CB-180) in pike (E. lucius), Arctic char (S. alpinus) and perch ( $P$. fluviatilis) to evaluate (1) concentrations over time in relation to imposed bans and restrictions; (2) spatial congener differences across Sweden; (3) concentrations against set environmental target levels; and (4) how monitoring design may affect the interpretation of these trends.

\section{MATERIALS AND METHODS}

\section{Study species}

The European perch is the most common freshwater fish in Sweden, and is also found in the brackish Baltic Sea (Kullander et al. 2012). Perch is an opportunistic predatory fish that undergoes an ontogenetic shift in diet (Collette et al. 1977; Kullander et al. 2012); small perch (5-30 mm) feed primarily on zooplankton, intermediate size $(30-80 \mathrm{~mm})$ on crustaceans, larvae and small fish, while large perch feed exclusively on fish and crayfish. Larger perch are thus exposed to biomagnifying substances at a high level of the aquatic food chain. The age at dietary shift is dependent on growth rate of perch, which can vary between lakes (Holmgren and Appelberg 2001). Perch muscle tissue is lean and contains approximately $0.3-0.6 \%$ of extractable fat (Nyberg et al. 2013).

Pike is also a common fish in the Nordic countries and can be found in both fresh and brackish water (Baltic Sea). Pike is mainly piscivorous but occasionally also feeds on frogs, small mammals and sea birds (Kullander et al. 2012). As this species is located at a high trophic level, the concentrations of biomagnifying compounds such as POPs, are normally high. Pike is a lean fish with an average muscle fat content of $0.6 \%$ (Nyberg et al. 2013).

Arctic char inhabits upland fresh waters of the Swedish mountain area. Diet varies depending on prey availability, fish size and the presence of other competitive species. Small individuals generally feed on benthic invertebrates and plankton, while larger individuals feed on fish, including conspecifics (Kullander et al. 2012). Because of the high trophic position of the large, piscivorous individuals, the concentrations of POPs might be high. Among the three investigated fish species, Arctic char has the highest lipid content: 1-3\% (Nyberg et al. 2013). All three species are fairly stationary, thus appropriate for studying local contaminant concentrations.

\section{Sampling sites, number of samples, and sampling frequency}

A total of 32 lakes are included in the Swedish National Monitoring Program for Contaminants in Freshwater Biota (SNMPCFB). Approximately 20 of these lakes are located in the southern half of Sweden (Fig. 1). In general, only one species per lake was sampled, with three exceptions. The year of initial PCB analysis varied among the selected lakes (Table 1). To facilitate regional comparisons, selected lakes were chosen to avoid possible confounding factors that could influence contaminant concentration in the sampled fish tissues e.g., (1) lakes should not be influenced by local contamination and must have some protection against future exploitation, (2) land use surrounding the lakes should be well investigated and intensively farmed rural areas avoided, (3) areas of liming activities should be avoided, and (4) lakes should preferably be placed high in the drainage system and be oligo- or mesotrophic.

The earliest time-series for PCBs ( $\Sigma \mathrm{PCBs}$ ) in the freshwater environment are from the late 1960s (pike from two lakes, including one that represents the Arctic region in Sweden). The $\Sigma$ PCBs were estimated from 14 peaks on a packed column GC after calibration with Aroclor 1254 (Jensen et al. 1983). During 1988, analysis on a capillary column was introduced, allowing analysis of individual congeners (Eriksson et al. 1994). Pike has been analyzed for 


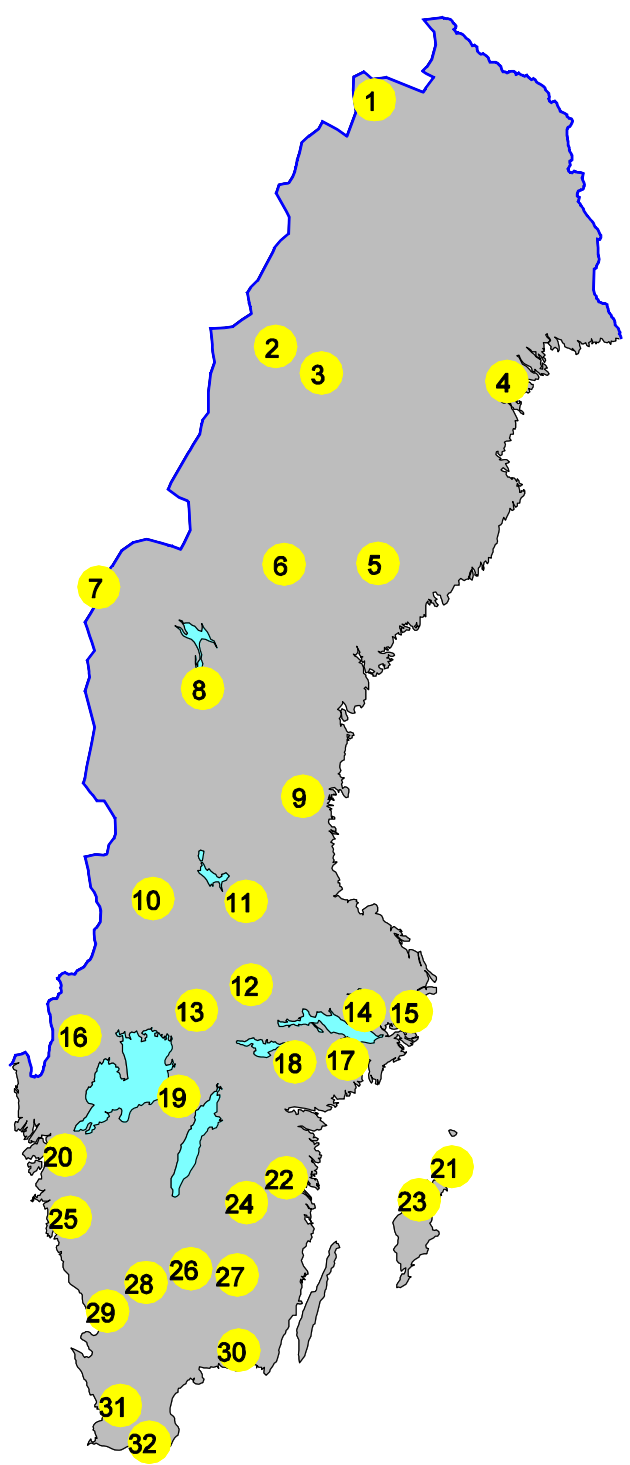

Fig. 1 Sampling sites within the Swedish National Monitoring Program for Contaminants in Freshwater Biota. See Table 1 for information about the different lakes

PCBs on an individual congener basis at two sites, Lake Bolmen, since 1988, and Lake Storvindeln since 1985 (Fig. 1; Table 1). Pike was collected in spring (April-May), during or soon after spawning. Arctic char was analyzed for PCBs on an individual congener basis at three sites-Lake Abiskojaure since 1981 (analyzed retrospectively), Lake Tjulträsk since 1986 and Lake Stor-Björsjön since 2007 (Fig. 1; Table 1). Char was sampled in the autumn (AugustNovember), usually during spawning. In recent years, perch was the most frequently sampled species and is currently collected from 27 lakes within the program (Fig. 1; Table 1). Perch has been analyzed for PCBs on an individual congener basis since 1997 in Lake Stensjön and 1999 in Lake Skärgölen (Table 1). Sampling of perch was carried out in autumn (August-October), outside of the spawning season.
Sampling has been carried out annually throughout the duration of the program. Prior to 2011, ten individuals of each species were analyzed annually from each lake, either individually or as a pooled sample. However, since 2011, twelve individuals have been analyzed as a pool (Table 1) (Bignert et al. 2013). A lower sampling frequency and sampling size than twelve individuals would result in a considerable decrease of statistical and interpretational power (Bignert et al. 1993). During 2001-2005, several of the collected samples were not analyzed but instead stored frozen at -20 or $-80^{\circ} \mathrm{C}$ in the Environmental Specimen Bank (ESB). Samples from nine of the 32 lakes were analyzed annually for PCBs since 2007 (Lake Abiskojaure, Lake Bolmen, Lake Horsan, Lake Krankesjön, Lake Skärgölen, Lake Stensjön, Lake Tjulträsk, Lake Storvindeln, and Lake Svartsjön), with the exception of Lake Svartsjön, which was analyzed annually since 2011. Of these nine lakes, six have been analyzed for more than 10 years (Table 1). The rest of the 32 lakes have been analyzed for PCBs only one to three times since sampling started.

\section{Sample preparation and registered variables}

For each fish, total body weight, body length, total length (body length plus the tail fin), sex, age, gonad weight, liver weight, and sample weight were recorded (Nyberg et al. 2013). To avoid surface contamination and to obtain a sample consisting of only muscle tissue, the epidermis and subcutaneous fatty tissue were carefully removed before the muscle tissue was excised. Muscle samples were taken from the middle dorsal muscle layer (TemaNord 1995). For the individual analyses, $10 \mathrm{~g}$ of muscle was taken from each fish; for the pooled samples, $1 \mathrm{~g}$ of muscle was taken from each fish (in total $10-12 \mathrm{~g}$ in each pool). The sampling and sample preparations were all performed according to the manual for collection, preparation, and storage of fish (SMNH 2012).

\section{Chemical analysis}

Samples were extracted using a mixture of polar and nonpolar solvents. The lipid content of the organic phase was determined gravimetrically. After clean-up of the dissolved lipid extracts using concentrated sulfuric acid, the samples were analyzed on a gas chromatograph equipped with a $\mu$ electron capture detector and two $60 \mathrm{~m}$ columns with different polarity used in parallel (Jensen et al. 1983; Eriksson et al. 1997). One internal laboratory reference material (LRM) of muscle from fish was used at every extraction event since 1994. Four different materials have been used during this period with lipid content from 0.54 to $5.9 \%$. Within-laboratory reproducibility was calculated from the LRMs for more than 8000 PCB values for all analyzed congeners, and 
Table 1 Sampling sites, coordinates, species and number of years analyzed for PCBs (individual congeners) within the Swedish National Monitoring Program for Contaminants in Freshwater Biota. The first column refers to the sampling site numbers in Fig. 1

\begin{tabular}{|c|c|c|c|c|c|}
\hline $\mathrm{N}$ in map & Lake & Latitude & Longitude & Species & Years analyzed for PCBs \\
\hline 1 & Abiskojaure & $68.31^{\circ}$ & $18.65^{\circ}$ & Arctic char & $81^{\mathrm{a}}, 86-98^{\mathrm{a}}, 00^{\mathrm{a}}, 07^{\mathrm{a}}, 08^{\mathrm{b}}, 09-10^{\mathrm{c}}, 11-12^{\mathrm{d}}$ \\
\hline 2 & Tjulträsk & $65.96^{\circ}$ & $16.07^{\circ}$ & Arctic char & $86-87^{\mathrm{a}}, 95^{\mathrm{a}}, 06^{\mathrm{b}}, 08-10^{\mathrm{c}}, 11-12^{\mathrm{d}}$ \\
\hline 3 & Storvindeln & $65.70^{\circ}$ & $17.13^{\circ}$ & Pike & $85-00^{\mathrm{a}}, 05^{\mathrm{a}}, 06^{\mathrm{b}}, 07^{\mathrm{a}}, 08^{\mathrm{b}}, 09^{\mathrm{c}}, 10^{\mathrm{b}}, 11-12^{\mathrm{d}}$ \\
\hline 4 & Brännträsket & $65.53^{\circ}$ & $21.42^{\circ}$ & Perch & $07^{\mathrm{b}}$ \\
\hline 5 & Remmarsjön & $63.86^{\circ}$ & $18.27^{\circ}$ & Perch & $00^{\mathrm{a}}, 05^{\mathrm{a}}, 07^{\mathrm{b}}$ \\
\hline 6 & Degervattnet & $63.87^{\circ}$ & $16.23^{\circ}$ & Perch & $05^{\mathrm{a}}, 07^{\mathrm{b}}$ \\
\hline 7 & Stor-Björsjön & $63.61^{\circ}$ & $12.23^{\circ}$ & Arctic char & $07^{\mathrm{b}}$ \\
\hline 8 & Stor-Backsjön & $62.68^{\circ}$ & $14.51^{\circ}$ & Perch & $07^{\mathrm{b}}$ \\
\hline 9 & Stensjön & $61.64^{\circ}$ & $16.58^{\circ}$ & Perch & $97-00^{\mathrm{a}}, 05^{\mathrm{a}}, 06^{\mathrm{b}}, 07^{\mathrm{a}}, 08^{\mathrm{b}}, 09^{\mathrm{c}}, 10^{\mathrm{b}}, 11-12^{\mathrm{d}}$ \\
\hline 10 & Gipsjön & $60.65^{\circ}$ & $13.63^{\circ}$ & Perch & $07^{\mathrm{b}}$ \\
\hline 11 & Spjutsjön & $60.64^{\circ}$ & $15.45^{\circ}$ & Perch & $07^{\mathrm{b}}$ \\
\hline 12 & Övre Skärsjön & $59.84^{\circ}$ & $15.55^{\circ}$ & Perch & $05^{\mathrm{a}}, 07^{\mathrm{b}}$ \\
\hline 13 & Limmingsjön & $59.59^{\circ}$ & $14.51^{\circ}$ & Perch & $07^{\mathrm{b}}$ \\
\hline 14 & Fysingen & $59.57^{\circ}$ & $17.92^{\circ}$ & Perch & $07^{\mathrm{b}}, 10^{\mathrm{b}}, 11-12^{\mathrm{e}}$ \\
\hline 15 & Tärnan & $59.56^{\circ}$ & $18.37^{\circ}$ & Perch & $05^{\mathrm{a}}, 07^{\mathrm{b}}$ \\
\hline 16 & Bysjön & $59.30^{\circ}$ & $12.34^{\circ}$ & Perch & $05^{\mathrm{a}}, 07^{\mathrm{b}}$ \\
\hline 17 & Stora Envättern & $59.11^{\circ}$ & $17.35^{\circ}$ & Perch & $00^{\mathrm{a}}, 05^{\mathrm{a}}, 07^{\mathrm{b}}$ \\
\hline 18 & Älgsjön & $59.09^{\circ}$ & $16.37^{\circ}$ & Perch & $07^{\mathrm{b}}$ \\
\hline 19 & Svartsjön & $58.76^{\circ}$ & $14.22^{\circ}$ & Perch & $07^{\mathrm{b}}, 11-12^{\mathrm{d}}$ \\
\hline 20 & Fräcksjön & $58.15^{\circ}$ & $12.18^{\circ}$ & Perch & $07^{\mathrm{b}}$ \\
\hline 21 & Bästeträsk & $57.92^{\circ}$ & $18.94^{\circ}$ & Perch & $07^{\mathrm{b}}$ \\
\hline 22 & Allgjuttern & $57.95^{\circ}$ & $16.10^{\circ}$ & Perch & $07^{\mathrm{b}}$ \\
\hline 23 & Horsan & $57.87^{\circ}$ & $18.84^{\circ}$ & Perch & $07^{\mathrm{a}}, 08^{\mathrm{b}}, 09^{\mathrm{c}}, 10^{\mathrm{b}}, 11-12^{\mathrm{d}}$ \\
\hline 24 & Skärgölen & $57.78^{\circ}$ & $15.58^{\circ}$ & Perch & $99^{\mathrm{a}}, 06^{\mathbf{b}}, 08^{\mathrm{b}}, 09-10^{\mathrm{c}}, 11-12^{\mathrm{d}}$ \\
\hline 25 & Lilla Öresjön & $57.56^{\circ}$ & $12.34^{\circ}$ & Perch & $07^{\mathrm{b}}$ \\
\hline 26 & Fiolen & $57.09^{\circ}$ & $14.53^{\circ}$ & Perch & $07^{\mathrm{b}}$ \\
\hline 27 & Hjärtsjön & $57.05^{\circ}$ & $15.26^{\circ}$ & Perch & $00^{\mathrm{a}}, 05^{\mathrm{a}}, 07^{\mathrm{b}}$ \\
\hline 28 & Bolmen & $56.97^{\circ}$ & $13.77^{\circ}$ & Pike & $88-00^{\mathrm{a}}, 05^{\mathrm{a}}, 06^{\mathrm{b}}, 07^{\mathrm{a}}, 08^{\mathrm{b}}, 09-10^{\mathrm{c}}, 11-12^{\mathrm{d}}$ \\
\hline 29 & Stora Skärsjön & $56.67^{\circ}$ & $13.07^{\circ}$ & Perch & $97-98^{\mathrm{a}}, 07^{\mathrm{b}}$ \\
\hline 30 & Sännen & $56.33^{\circ}$ & $15.36^{\circ}$ & Perch & $07^{\mathrm{b}}$ \\
\hline 31 & Krankesjön & $55.70^{\circ}$ & $13.47^{\circ}$ & Perch & $07^{\mathrm{a}}, 08^{\mathrm{b}}, 09^{\mathrm{c}}, 10^{\mathrm{b}}, 11-12^{\mathrm{d}}$ \\
\hline 32 & Krageholmsjön & $55.50^{\circ}$ & $13.75^{\circ}$ & Perch & $07^{\mathrm{b}}$ \\
\hline
\end{tabular}

a 10 individual specimens per year, minor deviations occur

b 1 pool per year of 10 individuals

c 2 pools per year of 10 individuals per pool

d 2 pools per year of 12 individuals per pool

e 1 pool per year of 12 individuals

resulted in a reproducibility of $14 \%$ for all reported PCB congener values between 2 and $50 \mathrm{ng} \mathrm{g}^{-1}$ lipid weight (l.w.) and $8 \%$ for values above $50 \mathrm{ng} \mathrm{g}^{-1} \mathrm{l}$.w. The laboratory has participated in the periodic QUASIMEME (Quality Assurance of Information for Marine Environmental Monitoring in Europe) proficiency testing since 1993, with around $95 \%$ of all reported values being within \pm 2 standard deviations of the assigned value. The quantification limit (defined as ten times the standard deviation of the measured concentration as the concentration approaches zero) is estimated to approximately $2 \mathrm{ng} \mathrm{g}^{-1}$ l.w. for all discussed PCB congeners.

\section{Statistical analysis and maps}

For the temporal trend analysis, log-linear regression was performed for the entire investigated period and for the most recent 10 years using the yearly geometric mean values. In cases where the regression line had a poor fit, a 
Table 2 Arithmetic mean age, length, weight and extractable muscle fat content, $\pm 95 \%$ confidence intervals (CI) for samples within the Swedish National Monitoring Program in Freshwater Biota. For perch, the arithmetic mean value for 2007-2012 is presented. For Arctic char and pike, the arithmetic mean value for the whole monitoring period is presented. Presented in alphabetical order by lake

\begin{tabular}{|c|c|c|c|c|c|}
\hline Lake & Species & Age (years) $95 \% \mathrm{CI}$ & Length $(\mathrm{cm}) 95 \%$ CI & Weight (g) $95 \%$ CI & Fat content (\%) $95 \% \mathrm{CI}$ \\
\hline Allgjuttern & Perch & $4.6(4.4-4.9)$ & $18.0(17.6-18.4)$ & $56.6(51.7-61.4)$ & $0.54(0.39-0.70)$ \\
\hline Abiskojaure & Arctic char & $5.1(5.0-5.3)$ & $26.9(26.4-27.4)$ & $216(203-230)$ & $1.7(1.5-1.8)$ \\
\hline Bolmen & Pike & $5.2(5.0-5.3)$ & $54.1(53.3-54.9)$ & $1080(1040-1120)$ & $0.55(0.54-0.57)$ \\
\hline Brännträsket & Perch & $7.6(7.2-8.1)$ & $18.7(18.3-19.1)$ & $68.1(63.3-72.8)$ & $0.62(0.28-0.96)$ \\
\hline Bysjön & Perch & $5.4(5.1-5.7)$ & $17.3(17.0-17.6)$ & $52.9(49.8-56.0)$ & $0.68(0.36-0.99)$ \\
\hline Bästeträsk & Perch & $3.9(3.7-4.1)$ & $17.5(17.3-17.8)$ & $53.4(51.2-55.6)$ & $0.70(0.37-1.0)$ \\
\hline Degervattnet & Perch & $5.5(5.2-5.8)$ & $18.3(18.0-18.6)$ & $63.8(60.6-67.0)$ & $0.48(0.31-0.65)$ \\
\hline Fiolen & Perch & $4.4(4.2-4.7)$ & $18.0(17.6-18.3)$ & $61.5(57.5-65.5)$ & $0.60(0.43-0.76)$ \\
\hline Fräcksjön & Perch & $5.3(5.0-5.5)$ & $17.1(16.8-17.4)$ & $51.9(48.3-55.5)$ & $0.58(0.43-0.76)$ \\
\hline Fysingen & Perch & $4.7(4.4-4.9)$ & $17.1(16.8-17.4)$ & $53.4(50.0-56.8)$ & $0.54(0.46-0.62)$ \\
\hline Gipsjön & Perch & $6.4(6.2-6.6)$ & $17.3(17.0-17.7)$ & $56.1(52.7-59.5)$ & $0.52(0.41-0.62)$ \\
\hline Hjärtsjön & Perch & $3.6(3.4-3.7)$ & $18.7(18.3-19.0)$ & $68.7(64.9-72.6)$ & $0.76(0.44-1.1)$ \\
\hline Horsan & Perch & $5.3(5.1-5.6)$ & $19.0(17.6-20.4)$ & $58.4(55.6-61.3)$ & $0.68(0.62-0.74)$ \\
\hline Krageholmsjön & Perch & $2.5(2.3-2.7)$ & $17.5(16.9-18.1)$ & $70.6(61.0-80.2)$ & $0.63(0.49-0.77)$ \\
\hline Krankesjön & Perch & $3.1(3.0-3.3)$ & $19.5(16.5-22.5)$ & $59.6(56.6-62.6)$ & $0.50(0.45-0.56)$ \\
\hline Lilla Öresjön & Perch & $5.6(5.3-5.9)$ & $18.3(18.0-18.7)$ & $63.5(59.2-67.8)$ & $0.70(0.37-1.02)$ \\
\hline Limmingsjön & Perch & $4.9(4.7-5.2)$ & $17.5(17.2-17.9)$ & $55.8(52.7-58.9)$ & $0.65(0.54-0.76)$ \\
\hline Remmarsjön & Perch & $6.8(6.5-7.2)$ & $18.9(18.4-19.4)$ & $72.7(67.3-78.0)$ & $0.66(0.53-0.78)$ \\
\hline Skärgölen & Perch & $4.7(4.5-5.0)$ & $17.8(16.9-18.7)$ & $59.0(54.8-63.1)$ & $0.68(0.64-0.72)$ \\
\hline Spjutsjön & Perch & $3.9(3.7-4.1)$ & $18.2(17.9-18.4)$ & $62.0(59.1-64.9)$ & $0.72(0.52-0.92)$ \\
\hline Stora Envättern & Perch & $5.3(5.1-5.6)$ & $16.8(16.5-17.2)$ & $47.8(44.2-51.4)$ & $0.62(0.30-0.93)$ \\
\hline Stensjön & Perch & $7.4(7.0-7.7)$ & $19.0(18.3-19.7)$ & $63.3(61.1-65.6)$ & $0.60(0.54-0.65)$ \\
\hline Stora Skärsjön & Perch & $6.3(6.1-6.6)$ & $16.4(16.2-16.6)$ & $46.3(44.4-48.2)$ & $0.56(0.45-0.68)$ \\
\hline Stor-Backsjön & Perch & $6.5(6.2-6.7)$ & $18.4(18.1-18.6)$ & $63.8(61.1-66.5)$ & $0.65(0.47-0.82)$ \\
\hline Stor-Björsjön & Arctic char & $5.6(4.5-6.7)$ & $26.3(25.6-27.1)$ & $160(146-175)$ & $1.0(0.46-1.6)$ \\
\hline Storvindeln & Pike & $5.8(5.6-5.9)$ & $61.3(60.7-62.0)$ & $1630(1570-1680)$ & $0.58(0.57-0.60)$ \\
\hline Svartsjön & Perch & $7.3(6.5-8.1)$ & $15.6(14.7-16.5)$ & $39.1(31.0-47.1)$ & $0.70(0.59-0.80)$ \\
\hline Sännen & Perch & $5.7(5.5-6.0)$ & $17.0(16.7-17.3)$ & $47.5(44.1-51.0)$ & $0.59(0.39-0.79)$ \\
\hline Tjulträsk & Arctic char & $5.2(5.1-5.3)$ & $26.9(26.3-27.6)$ & 209 (193-225) & $1.5(1.3-1.6)$ \\
\hline Tärnan & Perch & $5.9(5.6-6.2)$ & $17.7(17.3-18.1)$ & $58.1(53.1-63.0)$ & $0.60(0.50-0.69)$ \\
\hline Älgsjön & Perch & $5.8(5.4-6.1)$ & $16.7(16.3-17.0)$ & $46.1(43.4-48.8)$ & $0.69(0.47-0.90)$ \\
\hline Övre Skärsjön & Perch & $6.4(6.1-6.7)$ & $18.5(18.2-18.8)$ & $64.6(61.1-68.1)$ & $0.63(0.58-0.67)$ \\
\hline
\end{tabular}

3-point running mean smoother was checked for statistical significance in comparison to the regression using ANOVA (Nicholson et al. 1998). Potential outliers in the temporal trends were detected as described in Hoaglin and Welsch (1978). Suspected outliers are indicated in the figures but were included in the statistical calculations. Values below level of quantification (LOQ) were replaced by LOQ divided by the square root of 2 prior to all statistical analyses. Power was fixed to $80 \%$. The minimum possible trend that could be detected during a 10-year monitoring period at a significance level of $5 \%$ was estimated and power analysis was also carried out. A significance level of $5 \%$ was used for all tests.
Spatial differences in PCB concentrations were evaluated using bar maps. The height of the bars represents the arithmetic mean for 2007-2012, or shorter if results were not available. Principal component analysis (PCA) was performed on the proportions of the individual PCB-congener concentrations to the $\Sigma$ PCBs to study differences in the species congener patterns and differences due to latitude. The percentage of each PCB-congener relative to the sum of congeners was calculated and log-transformed prior to PCA analysis. Before the PCA-scores were plotted they were centered and scaled to $100 \%$. Hotelling's $T^{2}$ test was used to check for possible significant differences in congener patterns. The statistical trend analysis and the bar maps were 

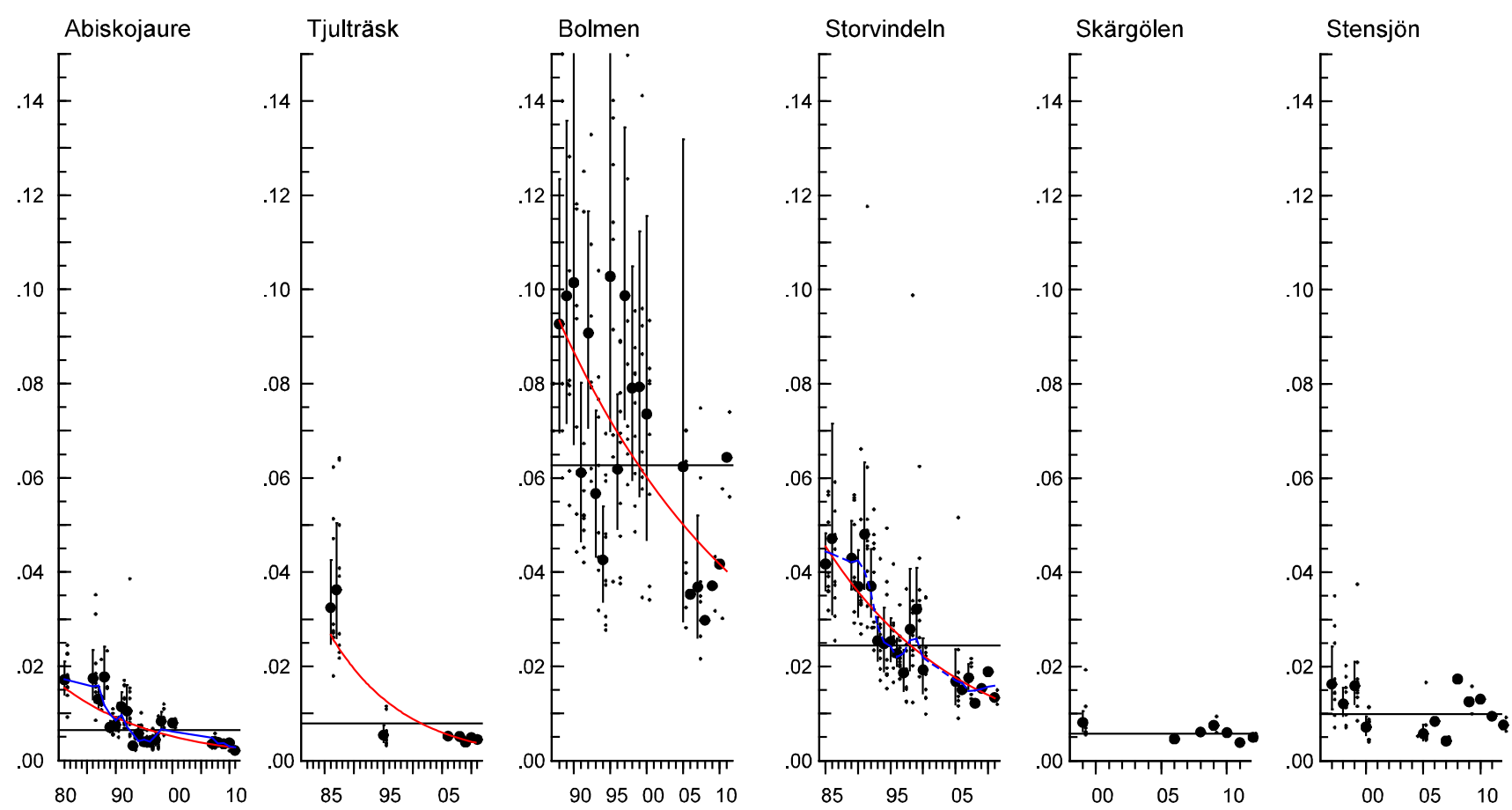

Fig. 2 Log-linear trends of CB-118 (ug $\mathrm{g}^{-1}$ lipid weight) in Arctic char muscle from Lake Abiskojaure and Lake Tjulträsk; in pike muscle from Lake Bolmen and Lake Storvindeln; and in perch muscle from Lake Skärgölen and Lake Stensjön (time series starting in 1981, 1986, 1988, 1985, 1997 and 1999, respectively). The red lines show a significant trend over the whole period and for the ten last years. The dark blue lines indicate non-linear trends $(0.05<p<0.1)$. The black horizontal line shows the mean concentration over the whole period. Each figure displays the geometric mean concentration of each year (circles) together with the individual analyses (small dots) and the $95 \%$ confidence intervals of the geometric means

performed for the dl-PCB, CB-118 $\left(2,3^{\prime}, 4,4^{\prime}, 5\right.$-pentachlorobiphenyl), and for the non dl-PCB CB-153 $\left(2,2^{\prime}, 4,4^{\prime}, 5,5^{\prime}-\right.$ hexachlorobiphenyl), both of which are dominant congeners in fish, as well as the ratio between the more easily degradable CB-101 (2,2'4,5,5'-pentachlorobiphenyl) and the more stable CB-153. CB-28 (2,4,4'-trichlorobiphenyl) was included in the bar maps to show a divergent pattern. In the PCA analysis, CB-118 was chosen as the only dl-PCB, while CB101, CB-153 and CB-180 (2,2'3,4,4',5,5'-heptachlorobiphenyl) were chosen as representing PCBs with different degrees of chlorination. All statistics are based on lipid normalized values. Statistical software PIA (www.amap.no) was used for the trend analysis and the PCAs. All the results for perch (except within the PCA) are based on data from 2007 to 2012 because data are most complete during that period, while for Arctic char and pike, the results are based on data for the whole monitoring period.

\section{Environmental assessment criteria}

In accordance with the Marine Strategy Framework Directive 2008/56/EC (MSFD), Good Environmental Status (GES) is defined as "concentrations of contaminants at levels not giving rise to pollution effects." To determine GES, a number of target levels have been established representing a threshold that should not be exceeded. These target levels should protect the most sensitive organisms from the harmful effects of hazardous substances and have been developed within several groups or conventions e.g., Environmental Quality Standards (EQS) developed within the EC to evaluate GES (2008/105/ EC), and the Environmental Assessment Criteria (EAC), developed within OSPAR (OSPAR 2009). For PCBs, EQSs are not established, so to evaluate concentrations of CB-118 and CB-153, OSPAR EACs are used in this study, and are 1.6 and $0.024 \mathrm{ug} \mathrm{g}^{-1}$ l.w., respectively (OSPAR 2009).

\section{RESULTS}

\section{Biological variables}

Arithmetic mean weight, age, length and muscle fat content are presented for samples from all lakes within the SNMPFB (Table 2). Perch size was similar among the lakes because they are chosen to be of similar size. By contrast, the age difference was large (2.5-7.6 years) between the lakes, with perch from the north being older. This is expected because fish grow more slowly in colder climates.

For Arctic char, both the age and total length were very similar between the three sampled lakes. For pike, 
Table 3 Lake, species, contaminant, the annual percentage change $\pm 95 \%$ confidence interval $(\mathrm{CI}), r^{2}$ reporting the coefficient of determination, $p$ value (significant at $<0.05$ ), the lowest detectable change (\% per year) for a ten year period with the current between year variation at a power of $80 \%$, coefficient of variation $(\mathrm{CV})$ around the regression line as a measure of between-year variation, and the number of years required to detect a trend of $10 \%$ at a power of $80 \%$ for CB-118, CB-153 and the ratio between CB-101:CB-153 in Arctic char, pike and perch (muscle). Data for the whole monitoring period are presented in the first row and for the most recent 10 years (2003-2012) in the lower row for each lake. Presented in order of contaminant

\begin{tabular}{|c|c|c|c|c|c|c|c|c|}
\hline Lake & Species & Contaminant & $\begin{array}{l}\text { Annual \% change } \\
(95 \% \mathrm{CI})\end{array}$ & $r^{2}$ & $p$ value & $\begin{array}{l}\text { Lowest detectable } \\
\text { change }(\%)\end{array}$ & $\mathrm{CV}(\%)$ & $\begin{array}{l}N \text { years required to } \\
\text { detect a trend of } 10 \%\end{array}$ \\
\hline Abiskojaure & Arctic char & CB-118 & & & & & & \\
\hline 1981-2012 & & & $-5.8(-7.8,-3.9)$ & 0.67 & $<0.001$ & 14 & 40 & 13 \\
\hline 2003-2012 & & & $-10(-22,2.2)$ & 0.57 & 0.084 & 6.7 & 19 & 9 \\
\hline Tjulträsk & Arctic char & CB-118 & & & & & & \\
\hline 1986-2012 & & & $-7.8(-11,-4.7)$ & 0.83 & $<0.001$ & 15 & 40 & 13 \\
\hline 2003-2012 & & & $-5.0(-12,1.5)$ & 0.54 & 0.098 & 4 & 11 & 7 \\
\hline Bolmen & Pike & CB-118 & & & & & & \\
\hline 1988-2012 & & & $-4.2(-6.0,-2.4)$ & 0.55 & $<0.001$ & 12 & 32 & 11 \\
\hline 2003-2012 & & & $-4.3(-18,9.5)$ & 0.08 & 0.48 & 14 & 38 & 12 \\
\hline Storvindeln & Pike & CB-118 & & & & & & \\
\hline 1985-012 & & & $-4.9(-6.0,-3.9)$ & 0.83 & $<0.001$ & 6.9 & 19 & 9 \\
\hline 2003-2012 & & & $-4.4(-12,2.7)$ & 0.28 & 0.18 & 6.9 & 19 & 9 \\
\hline Skärgölen & Perch & CB-118 & & & & & & \\
\hline 1999-2012 & & & $-3.6(-9.1,2.0)$ & 0.35 & 0.16 & 8.4 & 24 & 10 \\
\hline 2003-2012 & & & $-2.0(-17,13)$ & 0.03 & 0.72 & 9.4 & 26 & 10 \\
\hline Stensjön & Perch & CB-118 & & & & & & \\
\hline 1997-2012 & & & $-2.1(-7.8,3.6)$ & 0.06 & 0.44 & 17 & 48 & 14 \\
\hline 2003-2012 & & & $6.7(-11,24)$ & 0.13 & 0.39 & 18 & 49 & 14 \\
\hline Abiskojaure & Arctic char & CB-153 & & & & & & \\
\hline 1981-2012 & & & $-4.4(-5.9,-2.9)$ & 0.64 & $<0.001$ & 11 & 31 & 11 \\
\hline 2003-2012 & & & $-8.7(-13,-4.8)$ & 0.87 & $<0.01$ & 3.2 & 9.0 & 6 \\
\hline Tjulträsk & Arctic char & CB-153 & & & & & & \\
\hline 1986-2012 & & & $-7.2(-10,-4.5)$ & 0.85 & $<0.001$ & 13 & 36 & 12 \\
\hline 2003-2012 & & & $-2.5(-9.4,4.6)$ & 0.20 & 0.38 & 4.4 & 13 & 7 \\
\hline Bolmen & Pike & CB-153 & & & & & & \\
\hline 1988-2012 & & & $-1.2(-3.2,0.74)$ & 0.08 & 0.33 & 12 & 34 & 12 \\
\hline 2003-2012 & & & $-0.1(-14,14)$ & 0.00 & 0.95 & 14 & 39 & 13 \\
\hline Storvindeln & Pike & CB-153 & & & & & & \\
\hline 1985-012 & & & $-3.6(-4.6,-2.6)$ & 0.73 & $<0.001$ & 6.9 & 19 & 9 \\
\hline 2003-2012 & & & $-4.7(-9.5,0.18)$ & 0.48 & 0.055 & 4.6 & 13 & 7 \\
\hline Skärgölen & Perch & CB-153 & & & & & & \\
\hline 1999-2012 & & & $-1.6(-5.2,2.0)$ & 0.21 & 0.30 & 5.4 & 15 & 8 \\
\hline 2003-2012 & & & $-2.6(-12,6.9)$ & 0.13 & 0.49 & 5.9 & 17 & 8 \\
\hline Stensjön & Perch & CB-153 & & & & & & \\
\hline 1997-2012 & & & $0.57(-5.9,7.0)$ & 0.00 & 0.83 & 19 & 55 & 15 \\
\hline 2003-2012 & & & $12(-6.3,31)$ & 0.30 & 0.16 & 19 & 52 & 25 \\
\hline Abiskojaure & Arctic char & CB-101/CB-153 & & & & & & \\
\hline 1981-2012 & & & $-2.4(-3.4,-1.5)$ & 0.59 & $<0.001$ & 6.7 & 19 & 9 \\
\hline 2003-2012 & & & $2.6(-4.6,9.8)$ & 0.15 & 0.40 & 6.0 & 17 & 8 \\
\hline Tjulträsk & Arctic char & CB-101/CB-153 & & & & & & \\
\hline 1986-2012 & & & $-0.98(-2.0,0.052)$ & 0.42 & 0.058 & 4.6 & 13 & 7 \\
\hline 2003-2012 & & & $0.37(-5.9,6.7)$ & 0.00 & 0.85 & 3.9 & 11 & 7 \\
\hline Bolmen & Pike & CB-101/CB-153 & & & & & & \\
\hline 1988-2012 & & & $-2.5(-3.2,-1.7)$ & 0.71 & $<0.001$ & 4.6 & 13 & 7 \\
\hline
\end{tabular}


Table 3 continued

\begin{tabular}{|c|c|c|c|c|c|c|c|c|}
\hline Lake & Species & Contaminant & $\begin{array}{l}\text { Annual \% change } \\
(95 \% \mathrm{CI})\end{array}$ & $r^{2}$ & $p$ value & $\begin{array}{l}\text { Lowest detectable } \\
\text { change }(\%)\end{array}$ & CV (\%) & $\begin{array}{l}N \text { years required to } \\
\text { detect a trend of } 10 \%\end{array}$ \\
\hline 2003-2012 & & & $-2.7(-8.4,-2.9)$ & 0.19 & 0.28 & 5.4 & 15 & 8 \\
\hline Storvindeln & Pike & CB-101/CB-153 & & & & & & \\
\hline $1985-012$ & & & $-2.0(-2.7,1.3)$ & 0.63 & $<0.001$ & 4.8 & 13 & 7 \\
\hline 2003-2012 & & & $-0.41(-2.2,1.4)$ & 0.04 & 0.61 & 1.7 & 4.9 & 5 \\
\hline Skärgölen & Perch & CB-101/CB-153 & & & & & & \\
\hline 1999-2012 & & & $-1.9(-5.4,1.5)$ & 0.29 & 0.21 & 5.1 & 14 & 7 \\
\hline 2003-2012 & & & $0.60(-7.8,9.0)$ & 0.01 & 0.83 & 5.2 & 15 & 8 \\
\hline Stensjön & Perch & CB-101/CB-153 & & & & & & \\
\hline 1997-2012 & & & $-2.5(-4.1,-0.97)$ & 0.57 & $<0.01$ & 4.4 & 12 & 7 \\
\hline 2003-2012 & & & $-4.9(-9.4,-0.34)$ & 0.54 & $<0.05$ & 4.3 & 12 & 7 \\
\hline
\end{tabular}
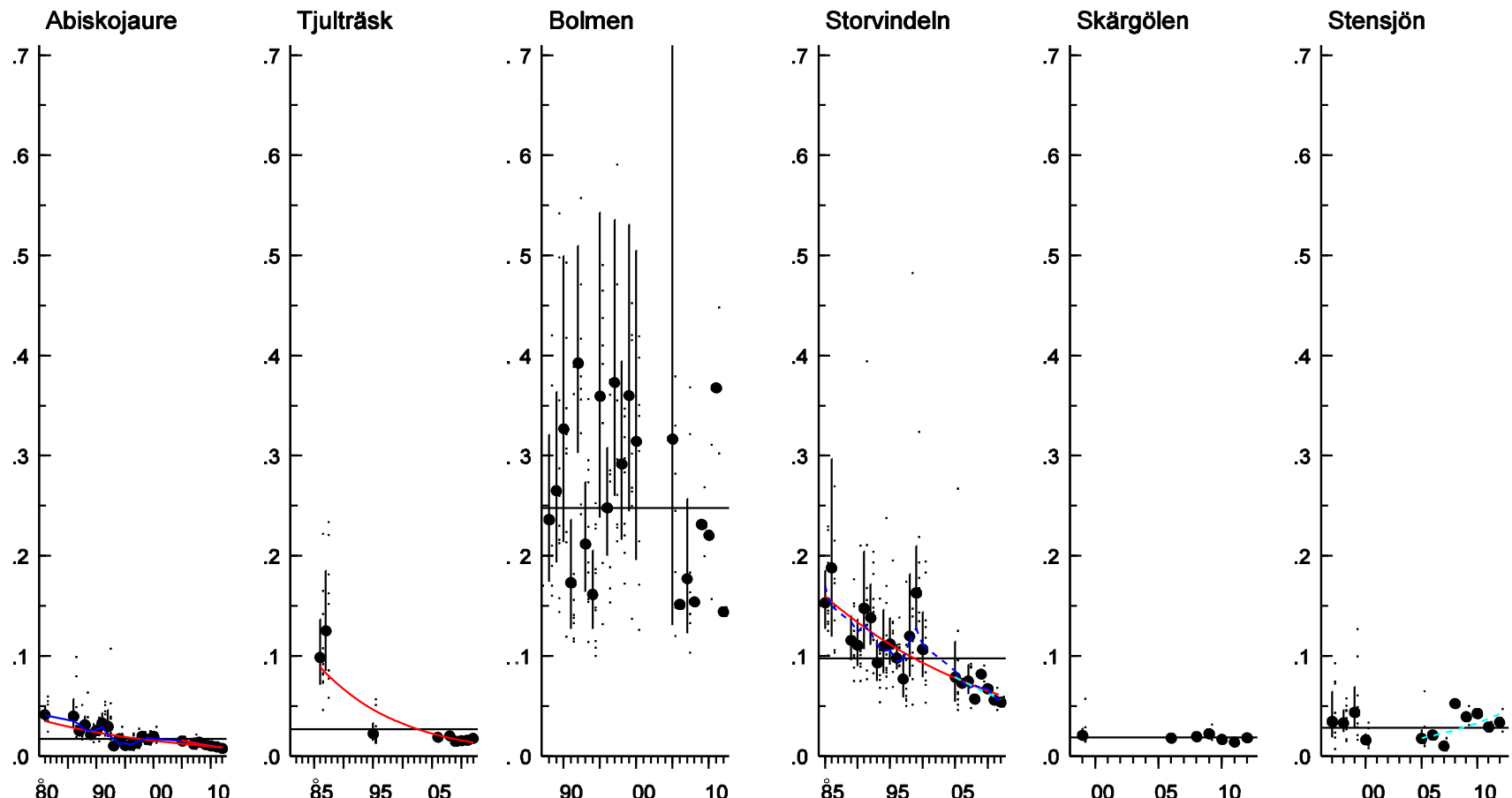

Fig. 3 Log-linear trends of CB-153 (ug g ${ }^{-1}$ lipid weight) in Arctic char muscle from Lake Abiskojaure and Lake Tjulträsk; in pike muscle from Lake Bolmen and Lake Storvindeln; and in perch muscle from Lake Skärgölen and Lake Stensjön (time series starting in 1981, 1986, 1988, 1985, 1997 and 1999, respectively). The red lines show significant linear trends over the whole period. The light blue dotted line indicates a trend for the last ten years $(0.05<p<0.2)$. The dark blue lines indicate non-linear trends $(0.05<p<0.1)$ and the black horizontal line the mean concentration over the whole period. Each figure displays the geometric mean concentration of each year (circles) together with the individual analyses (small dots) and the $95 \%$ confidence intervals of the geometric means

specimens from Lake Storvindeln were somewhat larger and less lean than pike from Lake Bolmen.

\section{Temporal trends}

In perch muscle samples, no trends were seen for $\mathrm{dl} C \mathrm{CB}-118$ in either sampled lake, but significant decreasing trends were seen for both Arctic char and pike muscle samples, of between
4.2 and $7.8 \%$ per year (Fig. 2; Table 3). As with CB-118, no trends were seen for $\mathrm{CB}-153$ in perch muscle from Lake Skärgölen or Lake Stensjön over the whole period (Fig. 3), but the statistical power to detect trends was relatively low. Concentrations of CB-153 in Arctic char decreased significantly in both lakes (between 4.4 and $7.2 \%$ per year). CB-153 in pike showed no trend in Lake Bolmen, but decreased significantly in Lake Storvindeln (3.6\% per year) (Fig. 3; Table 3). 

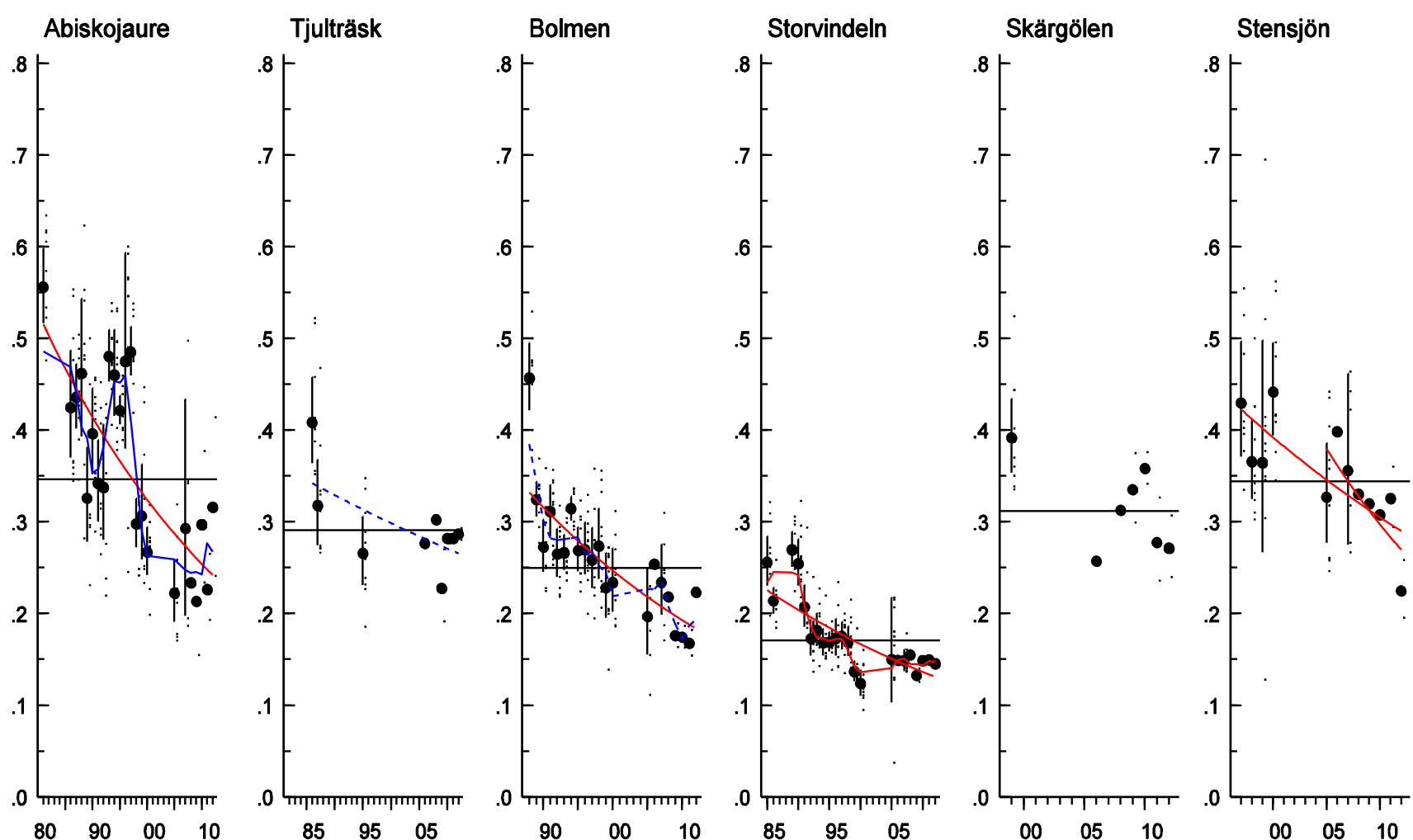

Fig. 4 Log-linear trends of the CB-101/CB-153-ratio in Arctic char muscle from Lake Abiskojaure and Lake Tjulträsk; in pike muscle from Lake Bolmen and Lake Storvindeln; and in perch muscle from Lake Skärgölen and Lake Stensjön (time series starting in 1981, 1986, 1988, 1985, 1997 and 1999, respectively). The red linear and non-linear lines show a significant trend over the whole period and for the ten last years. The dark blue lines indicate non-linear trends $(0.05<p<0.1)$. The black horizontal line shows the mean concentration over the whole period. Each figure displays the geometric mean concentration of each year (circles) together with the individual analyses (small dots) and the $95 \%$ confidence intervals of the geometric means

The number of years to detect a significant annual change of $10 \%$ with $80 \%$ statistical power for CB-153 and CB-118 varied: 11-13 years in Arctic char, 9-12 years in pike and 8-15 years in perch (Table 3). The statistical power to detect an annual change of $10 \%$ was very close to $100 \%$ in both the pike and Arctic char time series from Lake Abiskojaure for the entire period (not presented). Statistical power for the shorter perch time series and the Arctic char series from Lake Tjulträsk, which have fewer data points, varied between 37 and $77 \%$.

The ratio between the penta- and hexa-PCBs, as illustrated by CB-101/CB-153 (Fig. 4) has decreased over time in most lakes (between 2.0 and $2.5 \%$ per year), with the exception of Lake Skärgölen and Lake Tjulträsk, where there are few data points.

\section{Spatial patterns}

For both CB-153 and CB-118 (Fig. 5a, b) concentrations in perch muscle were lowest in lakes in the north of Sweden, highest around urban centres of the three largest cities in Sweden, Stockholm, Gothenburg and Malmö, as well as in
Karlskrona, an old naval city. Congener pattern differed between lakes. Lake Fysingen stands out with relatively high concentrations of the low chlorinated CB-28 (Fig. 5c). A similar pattern was observed when looking at the spatial distribution of CB-101/CB-153. Lower ratios were observed in the rural areas and higher ratios were observed in more densely populated regions (Fig. 5d).

Clear differences in congener pattern were seen between Arctic char and pike from the northern regions of Sweden (Fig. 6a). Pike generally has higher relative concentrations of CB-180 compared to the other two species, while Arctic char has relatively higher concentrations of CB-101. Perch from northern Sweden had a congener pattern between pike and Arctic char, and was significantly different from both of those species ( $p<0.05$, Hotelling's $T^{2}$ test).

\section{Target levels}

In all lakes and species, CB-153 concentration is below the OSPAR EAC of $1.6 \mathrm{ug} \mathrm{g}^{-1}$ l.w. (Figs. 3, 5a). The EAC for CB-118 of $0.024 \mathrm{ug} \mathrm{g}^{-1}$ lipid weight was exceeded in pike from Lake Bolmen and perch from Lake Krankesjön, Lake 


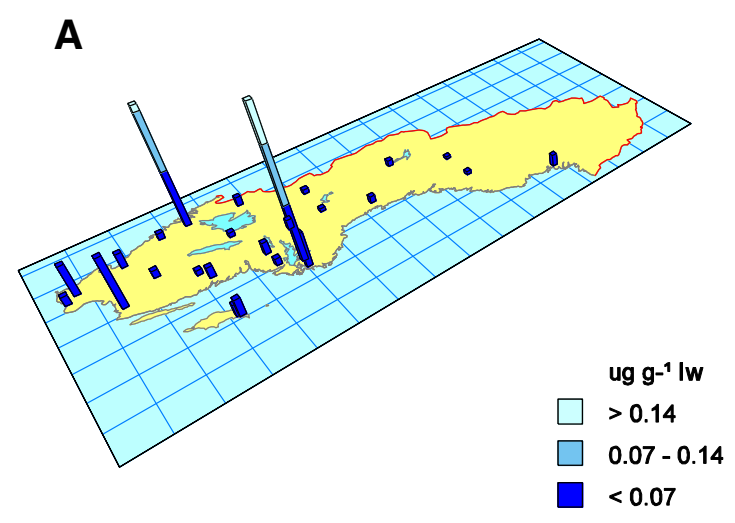

B
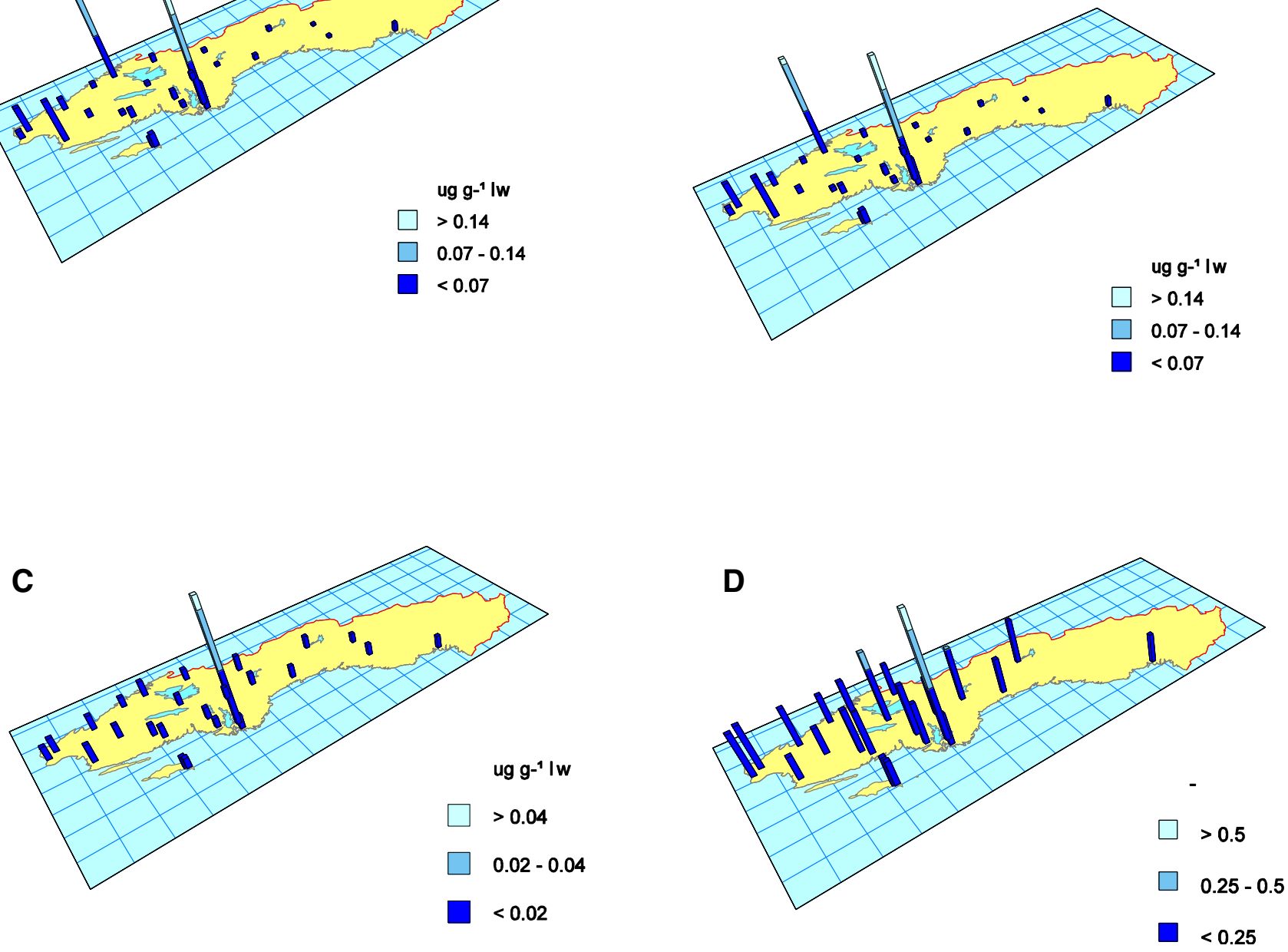

Fig. 5 Spatial variation in concentration (ug $\mathrm{g}^{-1}$ lipid weight) in freshwater perch muscle of a CB-153 b CB-118, c CB-28 and d the ratio between CB-101/CB-153; arithmetic mean values from 2007 to 2012

Sännen, Lake Fräcksjön, Lake Tärnan and Lake Fysingen (Figs. 2 and 5b) in 2007-2012.

\section{DISCUSSION}

The concentrations of PCBs, illustrated here by CB-118 and CB-153, were generally decreasing by about $3-8 \%$ per year in both pike and Arctic char. No trend was observed for the perch time series, but this is most likely due to the short duration of these time series and because monitoring in perch started after the steep decrease, during the 1980s and 1990s, observed for pike and Arctic char. Decreasing trends for PCBs in biological samples of similar magnitudes have been reported in studies from the Baltic Sea (Bignert et al. 2013; Miller et al. 2013) and other countries (e.g., Braune et al. 2005; Ryan et al. 2005; Helgason et al. 2008; Rigét et al. 2010). In a review on temporal trends of PCBs in arctic biota, Rigét et al.
(2010) found a mean annual decrease for CB-153 of $1.2 \%$ based on all the time series analyzed in the review (40 in total), which was somewhat lower than the decrease found in the time series here. A number of the time series presented in Rigét et al. (2010) started in the 1990s, later than the time series of our study, the concentrations were lower and the decrease less steep, which might explain the different results and the mean power in our time series were also considerably higher, $71 \%$ compared to $28 \%$ in Rigét et al. (2010).

The decrease over time, seen for concentrations of PCBs in both freshwater and marine fish in Sweden, mirrors the measures taken (e.g., bans and restrictions) to reduce PCBs in the environment. Gewurtz et al. (2010) found similar results as in our study for $\sum$ PCB, a steep decrease in the 1970s and 1980s, which levelled out in the mid-1990s, most probably as a result of bans and restrictions.

The ratio between the penta- (CB-101) and hexa-PCBs (CB-153) has decreased over time in most lakes. This 


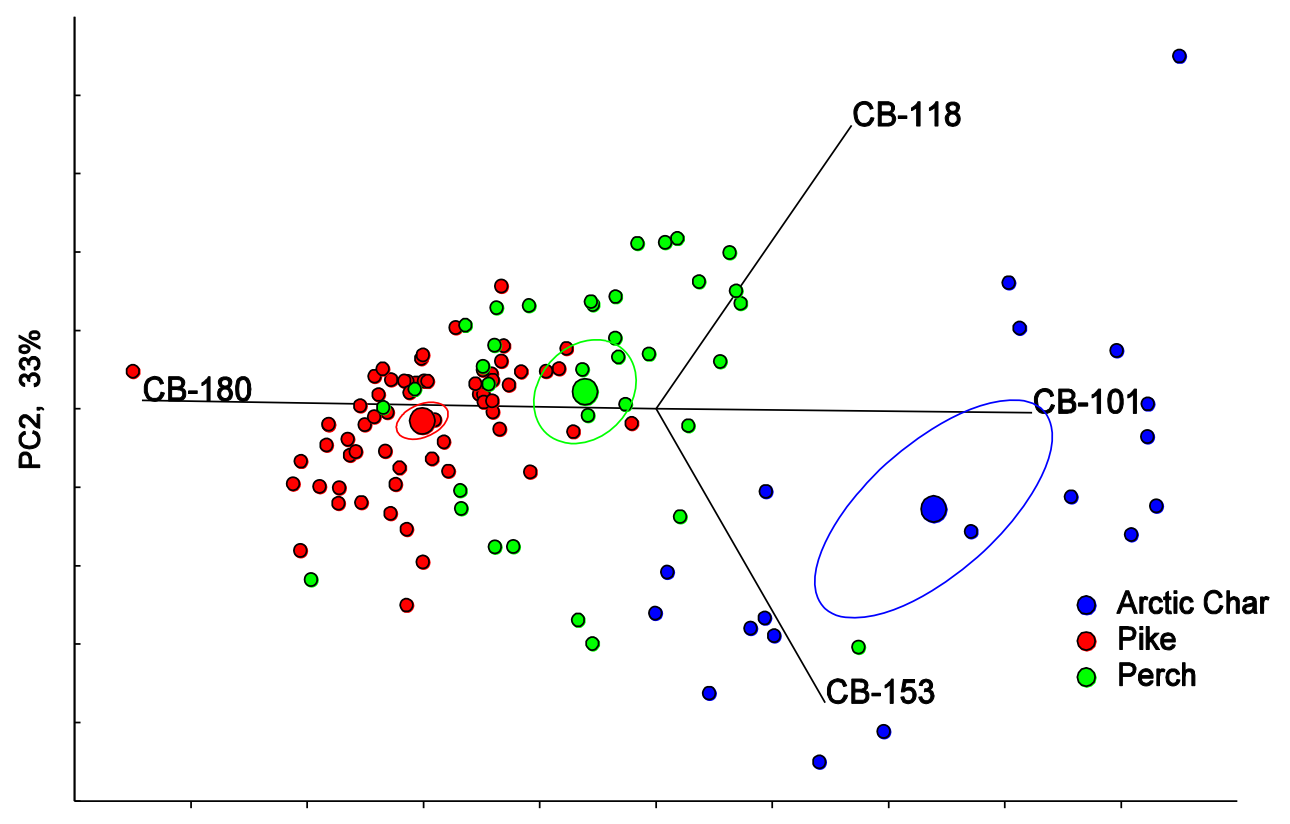

PC1, 43\%

Fig. 6 PCA (principal component analysis), biplot and Hotellings $95 \%$ confidence ellipses for center of gravity for each group. The figure shows PCB congeners (CB-101, CB-118, CB-153 and CB-180) in Arctic char, pike and perch (1997-2012) from the northern parts of Sweden, north between $61.00^{\circ}$ and $69.00^{\circ}$ latitude

decrease was expected due to a higher degree of volatilization and degradation of lower chlorinated PCBs. A decreasing ratio indicates that a temporal removal from the source has occurred. When locally contaminated lakes are identified, an increase in this ratio can be observed. During the last decade, the decrease appears to have levelled out at Lake Storvindeln and Lake Abiskojaure, which might indicate some change in PCB source in these areas. It is important that further studies are conducted to monitor the ratio of higher and lower chlorinated PCBs, as this may indicate releases of PCBs from new sources.

The concentrations of most PCBs (shown by CB-153 and CB-118) differ among lakes. It appears that lakes in the vicinity of urban and/or industrial areas (e.g., Lake Fysingen close to Arlanda airport and Lake Sännen close to the old naval city of Karlskrona), appear to be at greater risk of higher concentrations of PCBs compared to lakes in rural, less densely populated regions. Lake Fysingen stands out with not just high concentrations of CB-153 and CB-118, but also a high ratio of CB-101/CB-153 and relatively high concentrations of the lower chlorinated CB-28, indicating a new input of PCB. This needs to be investigated further to find out if this implies exposure from a new source or changes in land use around the lake. Turrio-Baldassarri et al. (1997) found that a relation between a persistent and a less persistent $\mathrm{CB}$-congener could indicate new contamination using the ratio between CB-149/CB-153 in cow milk.
The principal component analysis on perch, pike, and Arctic char from the northern parts of Sweden showed clear differences in congener pattern between Arctic char and pike, which might be explained by differences in diet, uptake of contaminants and metabolism. Perch also differed from both pike and Arctic char, but were more similar to pike. Babut et al. (2012) found that fish ecological traits are important factors that could explain differences in the bioaccumulation of PCBs when examining 2848 samples of 36 freshwater fish species from approximately 300 sites in France. However, Babut et al. (2012) also found that congener pattern in different fish species was more related to their physiology and metabolism than to their ecological traits. Arctic char in our study showed a lot of within-species variance, which could be expected because this species varies to a great extent both between and within lakes, likely because these species are present in more lake habitats and feed at more variable trophic levels compared with the other two species (Kullander et al. 2012).

The EAC for CB-118 was exceeded in pike from Lake Bolmen and perch from Lake Krankesjön, Sännen, Fräcksjön, Tärnan and Fysingen, which shows that the levels were still too high in some parts of the freshwater environment to protect the most sensitive organisms. Fish from Latvian lakes (including perch) show similar levels to that observed here for CB-118, with a mean value of $0.026 \mathrm{ug} \mathrm{g}^{-1}$ l.w. (recalculated from fresh weight to lipid 
weight basis) in fish muscle, which also exceeds the EAC (Zacs et al. 2013).

After $>40$ years of freshwater monitoring, some valuable lessons have been learned for developing the monitoring design of POPs. These include:

- Examination of individual congeners rather than only looking at the summed concentrations of a substance.

- The importance of annual monitoring.

- The choice of monitoring species, organ and selection of samples concerning e.g., age, sex, size, and sampling season.

- The importance of using the same laboratory for contaminant monitoring for temporal trend studies.

With a well-designed monitoring programme, small changes over time and space can be detected faster and this allows for focused remediation and policy efforts in specifically identified areas.

Acknowledgments The Swedish National Monitoring Program of Contaminants in Biota was financed by the Swedish Environmental Protection Agency. Mats Hjelmberg, Henrik Dahlgren, Jill Stavely Öhlund and Eva Kylberg at the Swedish Museum of Natural History are thanked for sample coordination and preparation.

Open Access This article is distributed under the terms of the Creative Commons Attribution License which permits any use, distribution, and reproduction in any medium, provided the original author(s) and the source are credited.

\section{REFERENCES}

Aulerich, R.J., and R.K. Ringer. 1977. Current status of PCB toxicity to mink, and effect on their reproduction. Archives of Environmental Contamination and Toxicology 6: 279-292.

Babut, M., S. Mathieu, S. Pradelle, P. Marchand, B. Le Bizec, and O. Perceval. 2012. Nationwide PCB congener pattern analysis in freshwater fish samples in France. Knowledge and Management of Aquatic Ecosystems 407: 07p1-07p17.

Bignert, A., A. Göthberg, S. Jensen, K. Litzén, T. Odsjö, M. Olsson, and L. Reutergårdh. 1993. The need for adequate biological sampling in ecotoxicological investigations: A retrospective study of twenty years pollution monitoring. Science of the Total Environment 128: 121-139.

Bignert, A., S. Danielsson, S. Faxneld, A. Miller, and E. Nyberg. 2013. Comments concerning the National Swedish Contaminant Monitoring Program in Marine Biota, 2013. Report Nr. 1:2013 to the Swedish EPA by the Department of Environmental Research and Monitoring at the Swedish Museum of Natural History, 259 pp.

Bleavins, M.R., R.J. Aulerich, and R.K. Ringer. 1980. Polychlorinated biphenyls (Aroclors 1016 and 1242): Effects on survival and reproduction in mink and ferrets. Archives of Environmental Contamination and Toxicology 10: 1432-0703.

Braune, B.M., P.M. Outridge, A.T. Fisk, D.C. Muir, P.A. Helm, K. Hobbs, P.F. Hoekstra, Z.A. Kuzyk, et al. 2005. Persistent organic pollutants and mercury in marine biota of the Canadian Arctic: An overview of spatial and temporal trends. Science of the Total Environment 351-352: 4-56.
Brázová, T., V. Hanzelová, D. Miklisová, D. Salgovicová, and L. Turceková. 2012. Biomonitoring of polychlorinated biphenyls (PCBs) in heavily polluted aquatic environment in different fish species. Environmental Monitoring and Assessment 184: 6553-6561.

Bredhult, C., B.-M. Bäcklin, A. Bignert, and M. Olovsson. 2008. Study of the relation between the incidence of uterine leiomyomas and the concentrations of PCB and DDT in Baltic grey seals. Reproductive Toxicology 25: 247-255.

Carpenter, D.O. 1998. Polychlorinated biphenyls and human health. International Journal of Occupational Medicine and Environmental Health 11: 291-303.

Carpenter, D.O. 2006. Polychlorinated Biphenyls (PCBs): Routes of exposure and effects on human health. Reviews on Environmental Health 21(1): 1-23.

Collette, B.B., M.A. Ali, K.E.F. Hokanson, M. Nagiec, S.A. Smirnov, J.E. Thorpe, A.H. Weatherley, and J. Williamsen. 1977. Biology of the percids. Journal of the Fisheries Research Board of Canada 34: 1890-1899.

Eriksson, U., A. Johansson, K. Litzén, L. Häggberg, A. Winberg, and S. Zakrisson. 1994. Analysmetod för bestämning av klorerade organiska miljögifter i biologiskt material. ITM report. (In Swedish).

Eriksson, U., L. Häggberg, A.-S. Kärsrud, K. Litzén, and L. Asplund. 1997. Analytical Method for Determination of Chlorinated Organic Contaminants in Biological Matrices. Report no. 59. Institute of Applied Environmental Science, Stockholm University. 22 pp.

Gewurtz, S.B., S.P. Bhavsar, D.A. Jackson, R. Fletcher, E. Awad, R. Moody, and E.J. Reiner. 2010. Temporal and spatial trends of organochlorines and mercury in fishes from the St. Clair River/ Lake St. Clair corridor, Canada. Journal of Great Lakes Research 36: 100-112.

Helander, B., M. Olsson, A. Bignert, L. Asplund, and K. Litzén. 2002. The role of DDE, PCB, coplanar PCB and eggshell parameters for reproduction in the white-tailed sea eagle (Haliaeetus albicilla) in Sweden. AMBIO 31: 386-403.

Helgason, L.B., R. Barrett, E. Lie, A. Polder, J.U. Skaare, and G.W. Gabrielsen. 2008. Levels and temporal trends (1983-2003) of persistent organic pollutants (POPs) and mercury ( $\mathrm{Hg}$ ) in seabird eggs from Northern Norway. Environmental Pollution 155: 190-198.

Helle, E., M. Olsson, and S. Jensen. 1976a. DDT and PCB levels and reproduction in ringed seal from the Bothnian Bay. AMBIO 5: $188-189$.

Helle, E., M. Olsson, and S. Jensen. 1976b. PCB levels correlated with pathological changes in seal uteri. AMBIO 5: 261-263.

Hoaglin, D.C., and R.E. Welsch. 1978. The hat matrix in regression and ANOVA. The American Statistician 32: 17-22.

Holmgren, K., and M. Appelberg. 2001. Effects of environmental factors on size related growth efficiency of perch, Perca fluviatilis. Ecology of Freshwater Fish 10: 247-256.

Jensen, S., L. Reutergårdh, and B. Jansson. 1983. Analytical methods for measuring organochlorines and methyl mercury by gas chromatography. FAO Fisheries Technical paper 212: 21-33.

Kullander, S.O., L. Nyman, K. Jilg, and B. Delling. 2012. Nationalnyckeln till Sveriges flora och fauna. Uppsala: Strålfeniga fiskar. Actinopterygii. Artdatabanken, SLU. (In Swedish).

Miller, A., J.E. Hedman, E. Nyberg, P. Haglund, I.C. Cousins, K. Wiberg, and A. Bignert. 2013. Temporal trends in dioxins (polychlorinated dibenzo-p-dioxin and dibenzofurans) and dioxin-like polychlorinated biphenyls in Baltic herring (Clupea harengus). Marine Pollution Bulletin 73: 220-230.

Nicholson, M.D., R.J. Fryer, and J.R. Larsen. 1998. Temporal trend monitoring: robust method for analyzing contaminant trend monitoring data. ICES Techniques in Marine Environmental Sciences 20: 1-22. 
Nyberg, E., S. Faxneld, S. Danielsson, and A. Bignert. 2013. The National Swedish Contaminant Monitoring Programme for Freshwater Biota, 2012. Report Nr. 13:2012 for the Swedish EPA by the Department of Environmental Research and Monitoring at the Swedish Museum of Natural History, $214 \mathrm{pp}$.

OSPAR. 2009. Agreement on CEMP Assessment Criteria for the QSR 2010. Agreement number: 2009-2.

Rigét, F., A. Bignert, B. Braune, J. Stow, and S. Wilson. 2010. Temporal trends of legacy POP's in Arctic biota, an update. Science of the Total Environment 408: 2874-2884.

Ryan, M.J., G.A. Stern, M. Diamon, M.V. Croft, P. Roach, and K. Kidd. 2005. Temporal trends of organochlorine contaminants in burbot and lake trout from three selected Yukon lakes. Science of the Total Environment 351-352: 501-522.

SMNH (Swedish Museum of Natural History). 2012. Manual for collection, preparation and storage of fish. http://www.nrm.se/ download/18.9ff3752132fdaeccb6800029077/1367705573979/ Fiskhandbok+1.0.pdf.

TemaNord 1995:543. Manual for Nordic Environmental Specimen Banking.

Turrio-Baldassarri, L., O. D’Agostino, E. De Felipe, A. Di Domenico, A.R. Fulgenzi, N. Iacovella, C. La Rocca, F. Rodriguez, et al. 1997. The ratio of $2,2^{\prime}, 4,4^{\prime}, 5^{\prime}, 6$-hexachlorobiphenyl (149) to $2,2^{\prime}, 4,4^{\prime}, 5,5^{\prime}$-hexachlorobiphenyl (153) as a possible degradational and analytical indicator. Microchemical Journal 55: 1-11.

Zacs, D., V. Bartkevics, and A. Viksna. 2013. Content of polychlorinated dibenzo-p-dioxins, dibenzofurans and dioxin-like polychlorinated biphenyls in fish from Latvian lakes. Chemosphere 91: 179-186.

Zanden, M.J., and J.B. Rasmussen. 1996. A trophic position model of pelagic food webs: Impact on contaminant bioaccumulation in lake trout. Ecological Monographs 66: 451-477.

\section{AUTHOR BIOGRAPHIES}

Elisabeth Nyberg $(\square)$ is a doctoral candidate at the Swedish Museum of Natural History. Her research interests include environmental monitoring, contaminants in biota and human milk.

Address: Department of Environmental Research and Monitoring, Swedish Museum of Natural History, Box 50007, 11418 Stockholm, Sweden.

e-mail: Elisabeth.Nyberg@nrm.se
Sara Danielsson has a master in environmental science and works at the Swedish Museum of Natural History. Her research interests include environmental monitoring and contaminants in biota.

Address: Department of Environmental Research and Monitoring, Swedish Museum of Natural History, Box 50007, 11418 Stockholm, Sweden.

e-mail: Sara.Danielsson@nrm.se

Ulla Eriksson is a research engineer at Stockholm University. Her research interests include analytical chemistry.

Address: Department of Applied Environmental Science, Stockholm University, Svante Arrhenius väg 8, 10691 Stockholm, Sweden.

e-mail: ulla.eriksson@itm.su.se

Suzanne Faxneld is a researcher $(\mathrm{PhD}$ in marine ecotoxicology) at the Swedish Museum of Natural History. Her research interests include marine ecotoxicology, environmental monitoring, and contaminants in biota.

Address: Department of Environmental Research and Monitoring, Swedish Museum of Natural History, Box 50007, 11418 Stockholm, Sweden.

e-mail: Suzanne.Faxneld@nrm.se

Aroha Miller is a research associate ( $\mathrm{PhD}$ in zoology) at the University of British Columbia. Her research interests include contaminants in marine and terrestrial animals and environmental issues. Address: Department of Applied Biology, University of British Columbia, 2357 Main Mall, Vancouver, BC V6T 1Z4, Canada. e-mail: aroha.miller@ubc.ca

Anders Bignert is a researcher and professor ( $\mathrm{PhD}$ in Zoology) at the Swedish Museum of Natural History. His research interest includes statistics and environmental monitoring.

Address: Department of Environmental Research and Monitoring, Swedish Museum of Natural History, Box 50007, 11418 Stockholm, Sweden.

e-mail: Anders.Bignert@nrm.se 